\title{
Surface modified nano-zeolite used as carrier for slow release of sulphur
}

\author{
M. Thirunavukkarasu* and K. S. Subramanian \\ Department of Nano Science and Technology, Tamil Nadu Agricultural University, Coimbatore-641003 \\ (Tamil Nadu), INDIA \\ *Corresponding author. E-mail: thirusac@gmail.com
}

Received: November 19, 2013; Revised received: February 1, 2014; .Accepted: February 10, 2014

\begin{abstract}
Surface modified nano-zeolite (SMNZ) was used as carrier to develop nano-zeolite based nano-sulphur fertilizer. A laboratory study on sulphur nano-fertilizer and conventional sulphur fertilizer were studied with percolation reactor system to evaluate the slow release of sulphur from both fertilizers in ambient temperature. SMNZ and sulphur nano-fertilizer were characterized using Fourier Transform Infrared Spectroscopy (FT-IR), Zeta Analyzer, Raman Spectroscopy, XRD and Scanning Electron Microscope (SEM). Raman spectroscopy confirmed the sulphur attachment at $480 \mathrm{~cm}^{-1}$ in the SMNZ. The FTIR spectra at $1030 \mathrm{~cm}^{-1}$ confirmed the sulphate attachments in the SMNZ spectrum. Zeta analyzer showed the surface charge of sulphur nano-fertilizer had (-) 52.6 $\mathrm{mV}$. SEM imaged the sulphur loaded SMNZ in irregular flake like structure. A comparative study of the release of sulphate $\left(\mathrm{SO}_{4}^{2-}\right)$ from fertilizer-loaded $\mathrm{SMNZ}$ and $\left(\mathrm{NH}_{4}\right)_{2} \mathrm{SO}_{4}$ fertilizers were performed using the percolation reactor. The results showed that the $\mathrm{SO}_{4}{ }^{2-}$ supply from fertilizer-loaded SMNZ was available even after $912 \mathrm{~h}$ of continuous percolation, whereas $\mathrm{SO}_{4}{ }^{2-}$ from $\left(\mathrm{NH}_{4}\right)_{2} \mathrm{SO}_{4}$ was exhausted within $384 \mathrm{~h}$. These properties suggest that SMNZ has a great potential as the fertilizer carrier for slow release of $\mathrm{SO}_{4}{ }^{2-}$.
\end{abstract}

Keywords: FT-IR, Percolation reactor, Slow release of sulphate, Surface modified nano-zeolite, XRD

\section{INTRODUCTION}

Sulphur is the fourth most important nutrient after nitrogen, phosphorus and zinc for Indian agriculture. Sulphur is best known for its role in the synthesis of proteins, oils, chlorophyll, amino acids, vitamins and flavoured compounds in plants (Sakal and Singh, 1997). Deficiency of sulphur is becoming widespread due to continuous use of sulphur free fertilizers, high yielding crop varieties, intensive multiple cropping system and high sulphur requiring crops along with the restricted or no use of organic manures have accrued in depletion of the soil sulphur reserve. The areas speculated as sufficient in sulphur had started showing sulphur deficiency after a period of intensive cultivation due to crop removal, organic matter losses, leaching and erosion losses and use of non-sulphur containing fertilizers (Biederbeck, 1978). Coleman (1966) noted that the incidence will be increasing due to widespread adoption of modern high productivity technologies. Sulphur, like N, occurs in soils in organic and inorganic forms, the former fraction often constituting more than $95 \%$ of the total S in most soils of India (Tabatabai, 1982).

Inglezakis and Grigoropoulou (2004) stated that the natural zeolites are hydrated aluminosilicates based on an infinite three-dimensional structure of tetrahedrons as $\mathrm{TO}_{4}(\mathrm{~T}=\mathrm{Si}, \mathrm{Al}, \mathrm{B}, \mathrm{Ge}, \mathrm{Fe}, \mathrm{P}, \mathrm{Co})$ joined by oxygen atoms. Zeolites have in its internal structure channels and cavities interconnected of molecular dimensions where compensation cations allowing the ion exchange exist (Kesraoui-Ouki et al., 1994). Zeolite materials allow an introduction of new functional groups through several processes of modification, improving substantially its activity and selectivity on the removal several substances (Inglezakis et al., 2001). Haggerty and Bowman (1994) showed that the use of modified natural zeolite on environmental applications, mainly anions uptake from effluents by adsorption processes. Surfactant-modified zeolite (SMZ) has been studied extensively due to its high capacity of sorption and retention of oxyanions such as chromate, nitrate, sulphate and phosphate (Li et al., 1998).

Perrin et al. (1998) stated that zeolite has high cation-exchange capacity and used as an inexpensive slow release fertilizer (SRF) carrier to carry and slowly release ammonium ions. Li and Zhang (2010) observed that sulfate release rate could be reduced by five to seven folds when SMZ was used and also results suggested that SMZ could be used as carriers for SRF to control sulphate release. Choudhury et al. (2010) reported that an improved synthesis of sulphur nano-particles and these sulphur nanoparticles exhibited fungicidal properties which were significantly superior to the conventional sulphur. Smaller size of nanosulphur and its coating will help resist unwanted environmental processes associated with conventional pesticides, i.e. leaching, 
evaporation, and photolytic, hydrolytic and microbial degradation. Kumar et al. (2011) revealed that the XRD spectrum of the synthesized sulphur nanoparticles showed a number of peaks at $13.57^{\circ}$, $22.98^{\circ}$ and $29.3^{\circ}$ with planes $(1,1,0),(0,0,2)$ and $(2$, $2,2)$ respectively (PCPDFWIN card no. 861278). This indicated the polycrystalline nature of sulphur nanoparticles.

The nano-zeolite based slow release nitrogen fertilizer in which release of nitrogen was continued even after $1176 \mathrm{~h}$ whereas urea fertilizer was exhausted after 192 h (Sharmila, 2010). The primary source of sulfur in nitrogen fertilizer was ammonium sulfate. The sulfur in sulfate fertilizers had the advantage of being immediately available to plants following their dissolution, while the disadvantage was a relatively large dose of sulfate released to the soil over a short period of time which was likely lost beyond the root zone of plants by leaching (Boswell and Gregg, 1998). Thus, an inexpensive fertilizer carrier that can curtain the sulfate release rate would be of great value. This research aims at evaluating release of sulfate from sulphate loaded surface modified nano-zeolite and conventional ammonium sulphate fertilizer in soil under glass column reactor study so that the release pattern of sulphate in SMNZ and ammonium sulphate fertilizer could be determined and the slow release effect of sulphate from both fertilizers assessed.

\section{MATERIALS AND METHODS}

Synthesis of nano-zeolite and surface modified nano -zeolite: The natural zeolite used in this study was epistilbite $\left(\mathrm{Ca}_{3}\left(\mathrm{Al}_{6} \mathrm{Si}_{18} \mathrm{O}_{48}\right) \cdot 16 \mathrm{H}_{2} \mathrm{O}\right)$, purchased from GM chemicals, India. In order to load the $\mathrm{SO}_{4}^{--}$ions, the negative surface charge of zeolite was modified by hexadecyltrimethylammoniumbromide (HDTMABr) (Sigma Aldrich Chemicals). Ultrapure distilled water was used throughout the experiments. Natural epistilbite zeolite was sieved through an analytical sieve of $0.5 \mathrm{~mm}$ mesh size. Nano-epistilbite was synthesized using a high energy ball milling (Fritsch-pulverisette 7, Germany). The milling was done in dry condition. During the course of experimentation, the milling conditions such as speed, duration and ball to powder ratio were standardized to reach size reduction and crystallinity retention. Accordingly, the milling speed, duration and balls to powder ratio were set as $600 \mathrm{rpm}, 6$ hours and 1:10, respectively. After six hours ball milling of natural zeolite in the bowl of high energy ball milling, the particle size of natural zeolite was reduced and also maintained the crystallinity of zeolite (Alizera and Gholamhosein, 2012; Subramanian and Sharmila Rahale, 2012).

The surface modification of nano-zeolite was done using a surfactant hexadecyltrimethylammoniumbromide (HDTMABr from Sigma Aldrich) (Li, 2003). Each $250 \mathrm{ml}$ shaking bottle was added with $60 \mathrm{~g}$ of nano-zeolite and $180 \mathrm{ml}$ of $135 \mathrm{mM} \mathrm{HDTMABr}$ solution and mixed on a reciprocal shaker for 24 hours at $150 \mathrm{rpm}$. Thereafter, the mixture was centrifuged at $5000 \mathrm{rpm}$ for 20 minutes. The solid portion of nano-zeolite after treated with various concentration of HDTMABr solution was dried for two weeks and surface modification of nano-zeolite was confirmed by Raman spectroscopy and X-ray diffarctometer.

Fortification of slow release sulphur fertilizer: Ammonium sulphate and surface modified nano-zeolite (1:4 ratios) were taken in the beaker. Ultrapure water was added until formation of few $\mathrm{cm}$ layer of supernatant solution above the solid portion. Stirred it with glass rod for 30 minutes. Then, kept the mixtures in the magnetic stirrer for two hours. Centrifuged the mixtures at $5000 \mathrm{rpm}$ for 20 minutes. Collected supernatant was discarded and solid portion was dried in vacuum drier to complete removal of water (Santhosh kumar, 2012). Finally slow release sulphur fertilizer was characterized by the Zeta analyzer, SEM, FT-IR, Raman spectroscopy and X-ray diffactometer.

\section{Characterization}

Scanning electron microscope (SEM): Surface morphology of the sulphate loaded surface modified nano-zeolite was characterized using Scanning electron microscope (SEM-FEI-Quanta 250). The powdered solid sample was initially placed on carbon tape of stuff which was kept in a vacuum chamber for coating with a thin layer (few nanometers) of gold (Au) by using sputter coater (EMITECH SC7620 sputter coater). After sputter coating, the stuff was kept inside the sample holder of the SEM and scanned for the purpose of imaging the area of interest.

Zeta analyzer: Zeta potential measurement for sulphate loaded SMNZ was determined using a zeta analyzer (Horiba, SZ-100). In the zeta analyzer, zeta potential measurement varied from $-200 \mathrm{mV}$ to 200 $\mathrm{mV}$. As a data acquisition time, usually less than one minutes for zeta potential measurement. $10 \mathrm{mg}$ of sample was taken in a $100 \mathrm{ml}$ beaker and added $50 \mathrm{ml}$ of millipore water. This sample was sonicated for 30 minutes in ultra sonicator. Then, the sample suspension was injected in electrode cell for measurement of zeta potential using zeta analyzer.

X-Ray diffractometer (XRD): The zeolite's lattice structure, crystalline size and d spacing of zeolite, unmodified nano-zeolite, surface modified nano-zeolite and sulphate loaded SMNZ were characterized using a pANALYTICAL-Xpert pro $\mathrm{X}$-Ray Diffractometer with $\mathrm{Cu} \mathrm{K}$ line as incident radiation and a filter at a scanning rate of $5^{\circ} \mathrm{s}^{-1}$. The powdered sample of $0.5 \mathrm{~g}$ was used for XRD measurement.

Fourier transform infrared spectroscopy (FT-IR): In this work, FT-IR spectra were recorded using a SHIMADZU equipped with a MCT detector. Two fifty six scans were recorded with a resolution of $4 \mathrm{~cm}^{-1}$. The most useful infrared region used for characterization of sulphate loaded SMNZ lies 
between 4000 and $500 \mathrm{~cm}^{-1}$. The term infrared covers the range of electromagnetic spectrum between 0.78 and $1000 \mu \mathrm{m}$. In the infrared spectroscopy, wavelength is usually measured in wavenumbers $\mathrm{cm}^{-1}$ ( wavenumber $=1 /$ wavelength in centimeters).

Raman spectroscopy: Raman spectra of zeolite, unmodified nano-zeolite, surface modified nano-zeolite and sulphate loaded SMNZ were obtained at room temperature with a raman system $(\mathrm{R}$ - 3000$\left.\mathrm{QE}^{\mathrm{TM}}\right)$ at dark condition. Solid probe of Raman system was used for measurement of material samples. Two to four gram of powdered solid sample was taken in glass tube and placed in sample holder and opened the RSIQ software in the system and laser light source was turned on in the instruments and finally the collect the Raman spectrum of sample using Raman spectroscopy.

Nutrient release by percolation reactor study: The experimental setup was basically the same as reported by (Bansiwal et al., 2006) except that the $72 \mathrm{~mL}$ day $^{-1}$ was replaced by a $20 \mathrm{~mL}$ day $^{-1}$. The percolation reactor consisted of a glass column (internal diameter $=1.5$ $\mathrm{cm}$; height $=25 \mathrm{~cm}$ ) through the top of which ultrapure water was continuously supplied at a flow rate of 20 $\mathrm{mL} \mathrm{day}^{-1}$. Inside the reactor, $10 \mathrm{~g}$ of soil overlaid with $1.0 \mathrm{~g}$ of fertilizer was placed. The leachates were collected every 48 hours from the reactors to determine $\mathrm{SO}_{4}$ concentration using the UV-visible spectrophotometric method at $420 \mathrm{~nm}$. This study was carried out until zero concentration or steady release of sulphate from the both fertilizer applied soil leachates. Two tests were performed as follows: one was slow release suphur nano-fertilizer and another with ammonium sulphate fertilizer $\left(\mathrm{NH}_{4}\right)_{2} \mathrm{SO}_{4}$. The ambient temperature during the experiment was $30^{\circ} \mathrm{C}$. For this study, soil was collected from the experimental garden land field. The Physicochemical Properties of experimental soil such as soil pH, EC, bulk density, particle density, porosity, water holding capacity, soil organic carbon, available sulphur, total sulphur, available nitrogen, phosphorus, potassium and micronutrients (zinc, copper, manganese and iron) were analyzed as per standard producers. The data and standard protocols are depicted in table 1 .

Statistical analysis: All measurements were made in triplicate and all values were expressed as the mean \pm standard error of the mean. The results were subjected to an analysis by Student's t- test. The results were considered statistically significant if the $p$ value was $\leq 0.05$.

\section{RESULTS AND DISCUSSION}

Surface morphology of sulphate loaded SMNZ: Surface morphology of sulphate loaded SMNZ was characterized using scanning electron microscope and depicted (Fig. 1). SEM image indicated that morphology of nano-zeolite was sphere like structure and after surface modification of nano-zeolite,

Table 1. Physico-chemical properties of experimental soil.

\begin{tabular}{|c|c|c|}
\hline Physico-chemical properties & $\begin{array}{l}\text { Measured } \\
\text { values }\end{array}$ & Standard methods \\
\hline Soil pH & 7.74 & Potentiometry (Jackson, 1973) \\
\hline Soil EC $\left(\mathrm{dSm}^{-1}\right)$ & 0.33 & Conductimetry (Jackson, 1973) \\
\hline Bulk density $\left(\mathrm{g} \mathrm{cc}^{-1}\right)$ & 1.25 & Cylindrical method (Gupta and Dhakshinamurthi, 1980) \\
\hline Particle density $\left(\mathrm{g} \mathrm{cc}^{-1}\right)$ & 1.82 & Cylindrical method (Gupta and Dhakshinamurthi, 1980) \\
\hline Porosity $(\%)$ & 31.30 & Cylindrical method (Gupta and Dhakshinamurthi, 1980) \\
\hline CEC (meq $\left.100 \mathrm{~g}^{-1}\right)$ & 21.52 & $\begin{array}{l}\text { Neutral Normal Ammonium Acetate method } \\
\text { (Schollenberger and Dreibelbis, 1930) }\end{array}$ \\
\hline Soil organic carbon $(\%)$ & 0.54 & $\begin{array}{l}\text { Wet chromic acid digestion method } \\
\text { (Walkley and Black, 1934) }\end{array}$ \\
\hline Available sulphur $\left(\mathrm{kg} \mathrm{ha}^{-1}\right)$ & 18.6 & $\begin{array}{l}0.15 \% \mathrm{CaCl}_{2} \text { extractable sulphur method } \\
\text { (Williams and Steinbergs, 1959) }\end{array}$ \\
\hline Available nitrogen $\left(\mathrm{kg} \mathrm{ha}^{-1}\right)$ & 210 & $\begin{array}{l}\text { Alkaline Potassium Permanganate method } \\
\text { (Subbiah and Asija, 1956) }\end{array}$ \\
\hline Available phosphorus $\left(\mathrm{kg} \mathrm{ha}^{-1}\right)$ & 25 & $0.5 \mathrm{M} \mathrm{NaHCO}_{3}$ method (Olsen et al., 1954) \\
\hline Available potassium $\left(\mathrm{kg} \mathrm{ha}^{-1}\right)$ & 524.1 & $\begin{array}{l}\text { Neutral Normal Ammonium Acetate method } \\
\text { (Hanway and Heidal, 1952) }\end{array}$ \\
\hline Available zinc (ppm) & 1.81 & DTPA Extractable Zn (Lindsay and Norvell, 1978) \\
\hline Available copper (ppm) & 2.42 & DTPA Extractable $\mathrm{Cu}$ (Lindsay and Norvell, 1978) \\
\hline Available manganese (ppm) & 21.01 & DTPA Extractable Mn (Lindsay and Norvell, 1978) \\
\hline Available iron (ppm) & 13.46 & DTPA Extractable Fe (Lindsay and Norvell, 1978) \\
\hline
\end{tabular}




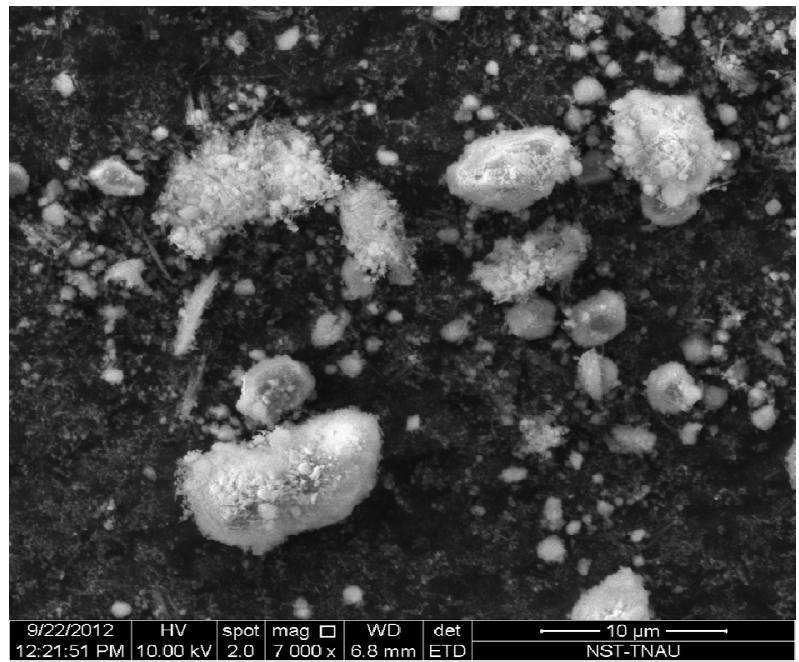

Fig. 1. Scanning Electron Microscope image of sulphate loaded surface modified nano-zeolite. morphology observed in irregular flakes like structure. Surface morphology of sulphate loaded SMNZ was characterized by SEM which showed that sulphate an ion was attached in to the SMNZ on its surface due to pore size of zeolite is ranged from two to $18 \mathrm{~nm}$ these results was similar with (Alizera and Gholamhosein, 2012).

Fourier transform Infrared Spectroscopy and zeta potential: The FTIR spectra of sulphate loaded SMNZ covering the wave numbers range from 400 to 4000 $\mathrm{cm}^{-1}$ were taken. The FT-IR spectra obtained using $\mathrm{KBr}$ pellets of the sulphate loaded SMNZ shows characteristic peaks at wave numbers of $3556.76,3421.72$, $2924.09, \quad 2858.51, \quad 2630.91, \quad 2534.46, \quad 2310.72$, 2056.12, 1809.23, 1651.07, 1450.47, 1029.99, 883.40, 721.38 and $478.35 \mathrm{~cm}^{-1}$ (Fig. 2a) Which indicate the sulphate attachment into SMNZ surface. Particularly, the presence of spectra peaks at $1029.99 \mathrm{~cm}^{-1}$ in the SMNZ spectrum (related to sulphur vibrations in the
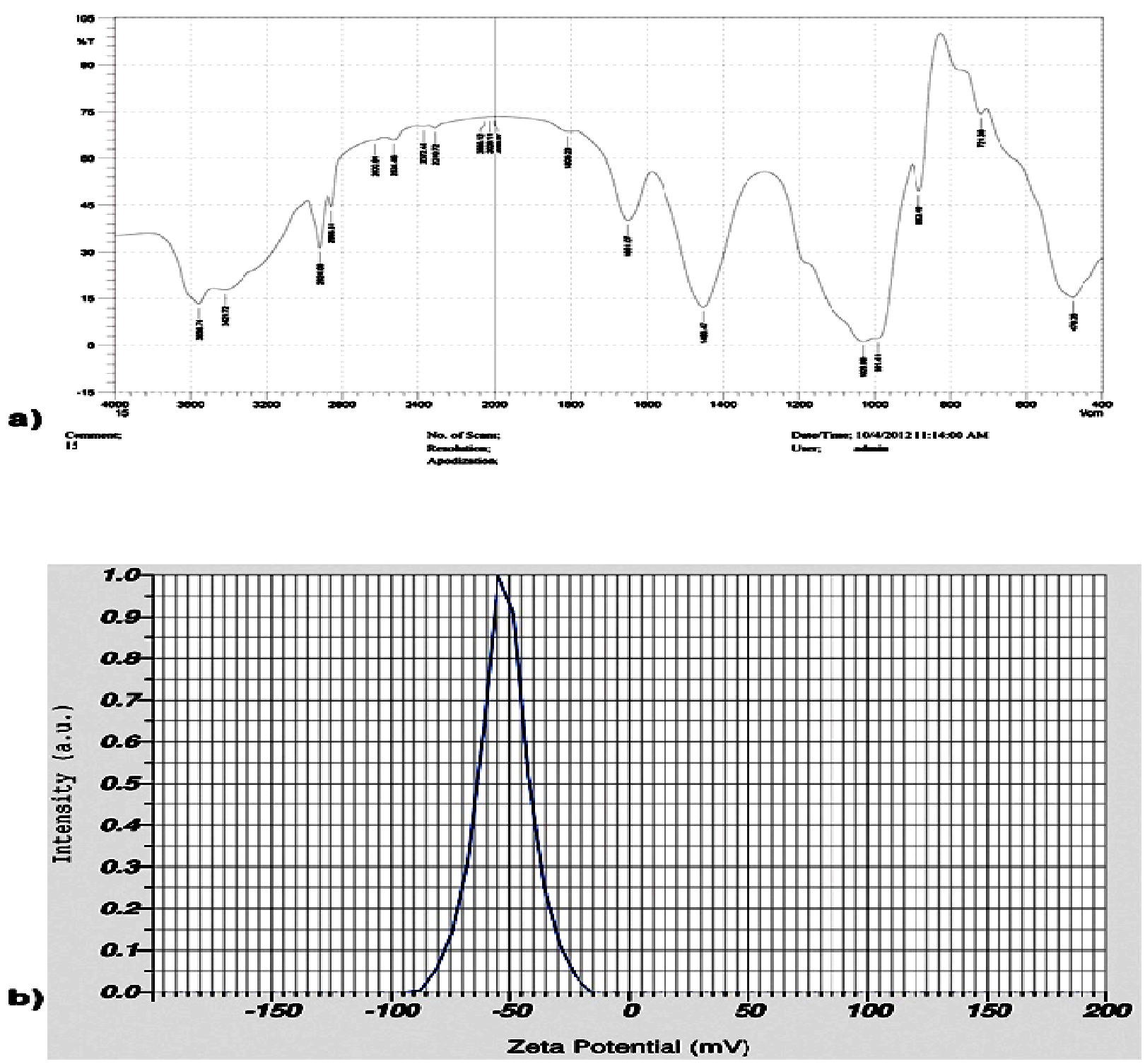

Fig. 2. FT-IR spectra (a) and Zeta potential (b) of sulphate loaded surface modified nano-zeolite. 

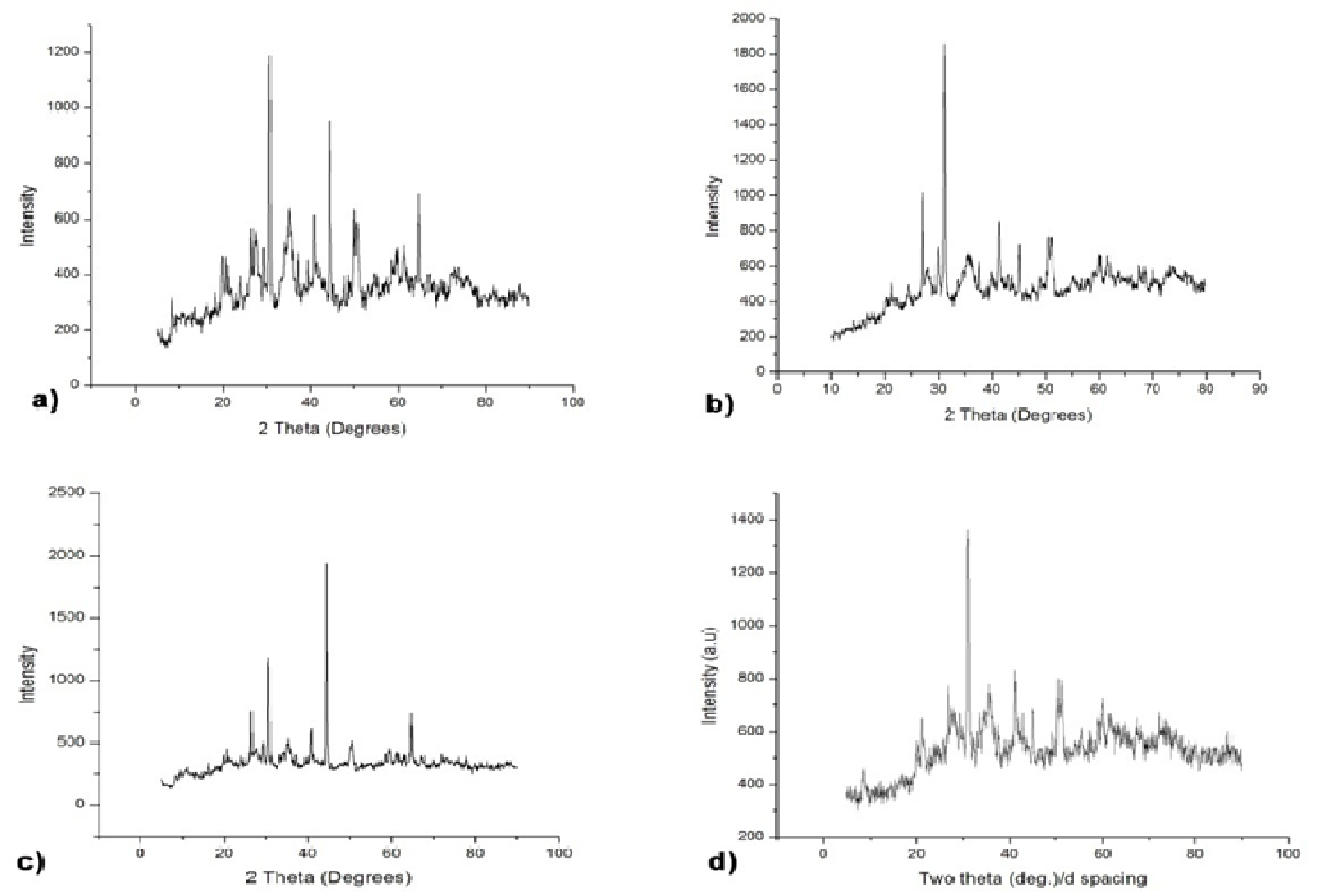

Fig. 3. X-ray diffraction of zeolite (a), nano-zeolite (b), surface modified nano-zeolite (c) and sulphate loaded SMNZ (d)
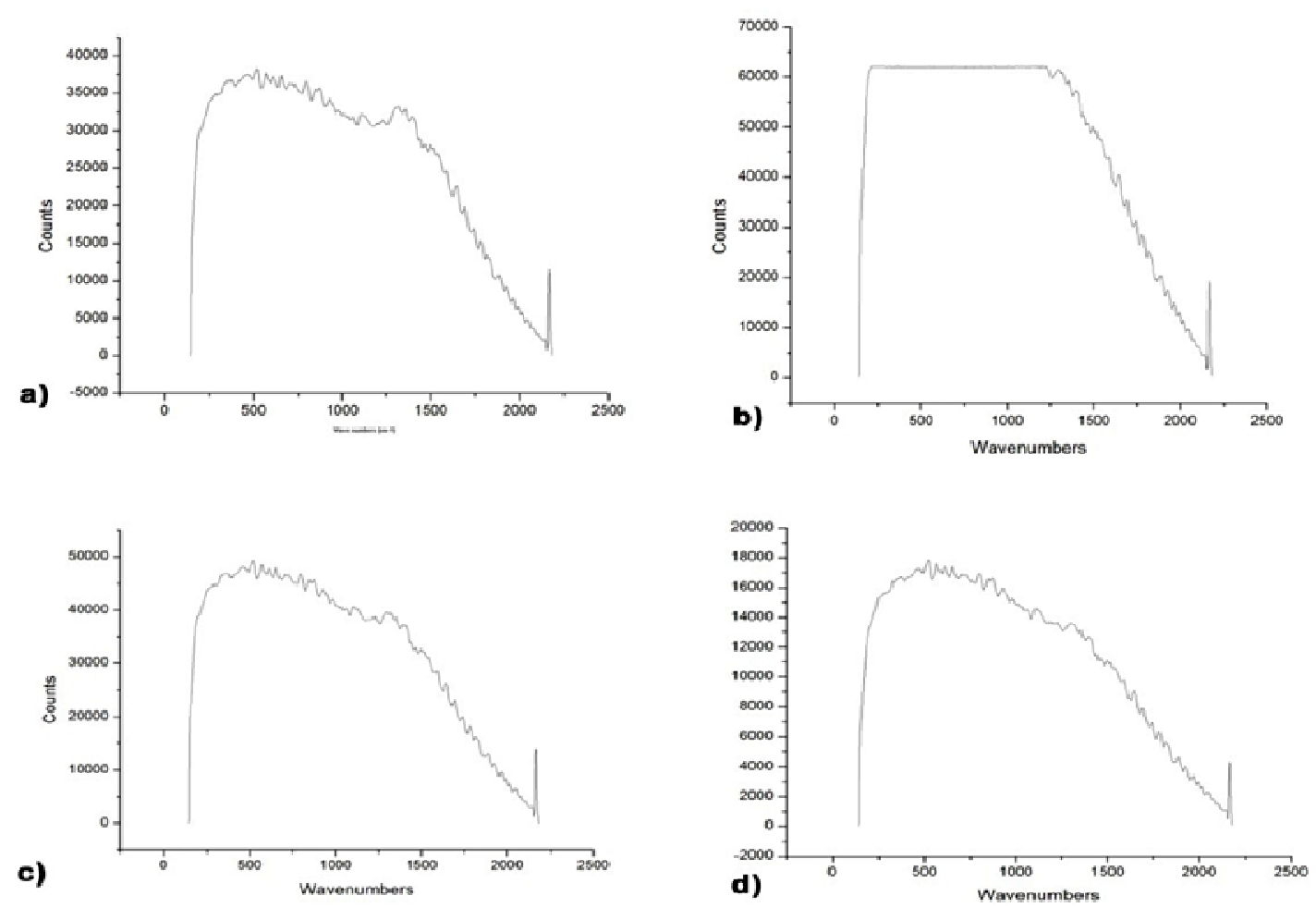

Fig. 4. Raman spectra of zeolite (a), nano-zeolite (b), surface modified nano-zeolite $(c)$ and sulphate loaded SMNZ (d)

SMNZ) that are absent in the surface modified nano-zeolite spectrum confirms the loading of sulphate onto the SMNZ surface. Sorption of inorganic anions on cationic surfactant modified nano-zeolite has been attributed to the formation of a surface-anion complex
(Bowman et al., 1995).

Zeta potential was characterized using zeta analyzer which showed that sulphate loaded surface modified nano-zeolite had surface negative charge of (-) 52.6 $\mathrm{mV}$ (Fig. 2b). The data clearly indicated that sulphate 


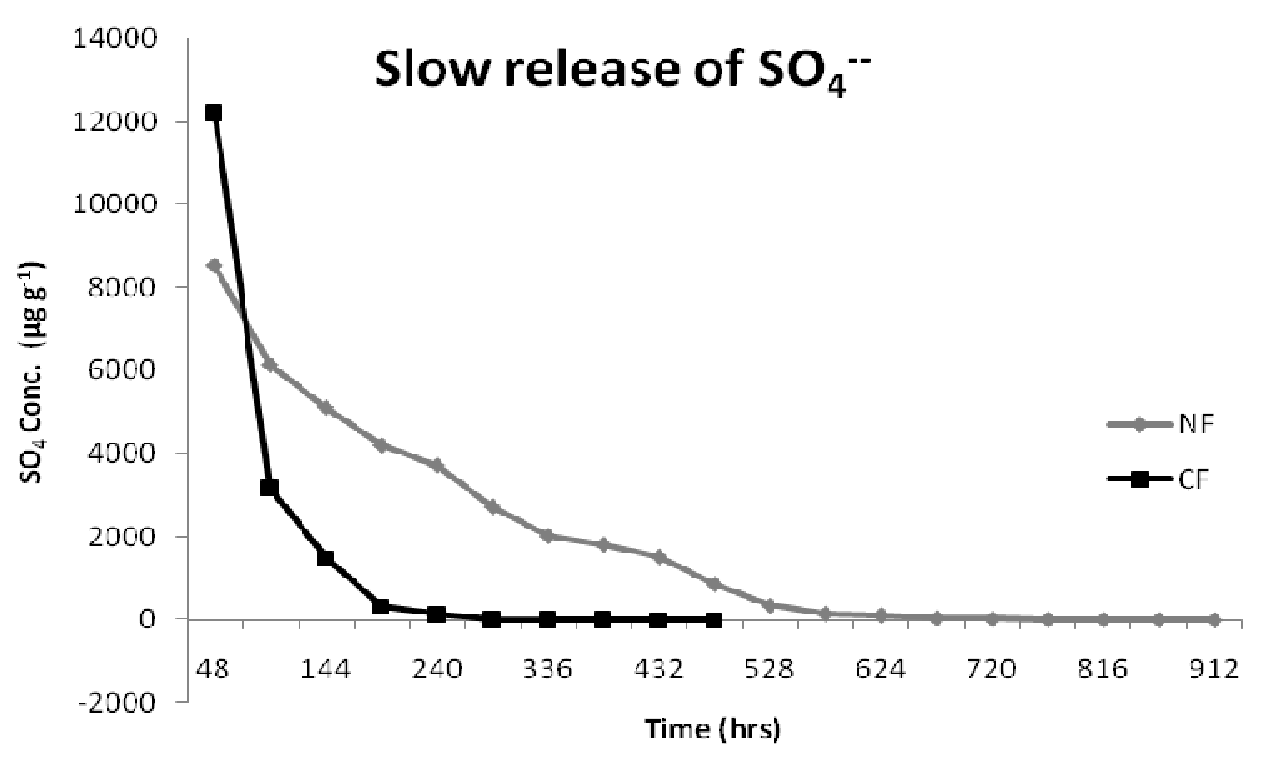

Fig. 5. Slow release of $\mathrm{SO}_{4}{ }^{2-}$ from pure $\left(\mathrm{NH}_{4}\right)_{2} \mathrm{SO}_{4}$ and $\mathrm{SO}_{4}{ }^{2-}$ loaded $\mathrm{SMNZ}$.

loading into the surface modified nano-zeolite was confirmed by the surface positive charge of SMNZ was changed into surface negative charge. Actually zeolite was carried negative charge on its surface, after the surface modification using HDTMBr surfactant has changed the negative charge to positive charge that might be facilitated retention of $\mathrm{SO}_{4}{ }^{--}$on its surface. The positive surface charge of surface modified nano-zeolite was changed into the negative surface charge after loading of sulphate ion in the SMNZ. These findings are in conformity with the findings of Bowman (2003) who have stated that the surfactant molecules form bilayers on zeolite external surfaces with the lower layer held by electrostatic interaction between the negatively charged zeolite surface and the positively charged surfactant head groups while the upper layer is bound to the lower layer by hydrophobic forces between the surfactant tail groups in both layers. Under the surfactant bilayer configuration, the zeolite reverses its surface charge, resulting in a higher affinity for negatively charged anions, and the sorption and retention of anions are attributed to surface anion exchange.

According to the DLVO (Derjaguin-Landau-VerweyOverbeek) theory, a potential barrier between surface charged particles in suspension may result in colloidal meta-stability. This theory takes into account van der Waals forces, as well as repulsion caused by the overlap of the electric double layer (EDL) around each particle. The double layer is formed in response to active surface group dissociation and/or selective chemisorption of charged species on the surface (Nikolakis, 2005).

X-ray diffraction of zeolites: The X-ray diffraction technique was used to identify the crystal structure and two theta values of the mineral. Powdered zeolite sample was used for XRD analyses. The XRD pattern of zeolite was examined by Xray diffraction techniques. The peaks at $2 \theta=13.63$, 20.67, 30.70, 35.11, 44.36, 50.03, 61.32, 64.73, 72.40 and 75.55 degree was observed for zeolite (Fig. 3a), whereas unmodified nano-zeolite (Fig. 3b) had characteristic shifted peaks at $2 \theta=27.08,31.18$, $35.69,41.37,45.20,50.50,60.06,67.57$ and 74.80 degrees. The peaks at $2 \theta=20.77,30.65,35.27,44.35$, $50.76,59.59$ and 64.74 degree were observed for surface modified nano-zeolite (Fig. 3c). The XRD spectra of surface modified nano-zeolite at $2 \theta=20.77$ degree confirmed the surface modification of nano-zeolite and corresponding $d$ spacing value is 4.27. The data on XRD spectra of sulphate loaded SMNZ had characteristic shifted peaks at $2 \theta=21.02$, $27.831 .03,35.76,41.12,50.49,60.02,67.42$ and 72.39 degree were observed (Fig. 3d). These shifted peaks of two theta values at 27.8 degree clearly showed that $\mathrm{SO}_{4}{ }^{2-}$ was loaded on the SMNZ. These results are agreement with finding of the Srinivasulu et al. (2012) who stated that the d spacing of sulphur was at 3.33 indicated the structural and chemical characteristic of the sulphur found as orthorhombic.

Raman spectroscopy study: The results of raman spectra for zeolite (Fig. 4a) and unmodified nano zeolite (Fig. 4b) were recorded peak of 568, 1641.4, 1690.8, 1742.8, 1779.3, $1965.7 \mathrm{~cm}^{-1}$ and 274.2, 568, 1644.9, 1690, 1742.8, 1779.3, $1964.1 \mathrm{~cm}^{-1}$ respectively. The vibrational frequencies of zeolite lattice, which result from stretching and bending modes of the $\mathrm{T}-\mathrm{O}(\mathrm{T}=\mathrm{Si}$ or $\mathrm{Al})$ units, are observed in the range between $250-500 \mathrm{~cm}^{-1}$ (Glanigen, 1976). The strongest and most structure-sensitive bands in the Raman spectrum of zeolites are generally between 300 and $600 \mathrm{~cm}^{-1}$ and have been assigned to the motion of an oxygen atom in a plane, perpendicular to the T-O-T bond, representing the most characteristic vibrational 
information of framework structures (Dutta et al. 1988). Raman spectra of pure zeolite and Al-, B-, Ti-, and Fe-substituted silicalites in the $\mathrm{Si}-\mathrm{O}$ stretching region (1500-1700 $\mathrm{cm}^{-1}$ ) systematically (Scarano et al., 1993).

Raman spectra of surface modified nano-zeolite (Fig. $4 \mathrm{c})$ had recorded peaks of $371.2,520.9,568,1641.4$, 1690.8, 1742.8, 1781 and $1965.7 \mathrm{~cm}^{-1}$. Zeolites built of four-membered rings as the smallest building block exhibit the Raman band around 480-520 $\mathrm{cm}^{-1}$ (Dutta et al. 1988). Besides the most intensive Raman bands of $\mathrm{Si}-\mathrm{O}-\mathrm{Si}$ or $\mathrm{Si}-\mathrm{O}-\mathrm{Br}$ deformation vibrations at $350-400$ $\mathrm{cm}^{-1}$. The frequency shifts around $300-500 \mathrm{~cm}^{-1}$ could be attributed to slight structural changes of the framework upon exchange of the extra framework cations (Smirnov and Bougeard, 1993). The intensity of raman peaks for sulphate loaded SMNZ was 371.2, 480.0, 1644.9, 1690.8, 1742.8, 1781, 1885.5 and $1965.7 \mathrm{~cm}^{-1}$ (Fig. 4d). The Raman spectra at $480.0 \mathrm{~cm}^{-1}$ confirmed the sulphate attachment in the surface modified nano-zeolite. These findings are corroborate with the results of Himmel et al. (2009) who found that Raman bands at $480 \mathrm{~cm}^{-1}$ characteristic of the presence of sulphur in the surface modified nano-zeolite.

Slow release of sulphate: The pure fertilizer $\left(\mathrm{NH}_{4}\right)_{2}$ $\mathrm{SO}_{4}$ and sulphate-loaded surface modified nano-zeolite were subjected to sulphate release using the percolation reactors. The reactor with soil and without fertilizer provided only non detectable amount of sulphate. Therefore, all of the sulphate measured from the leachates obtained from reactors having soil plus fertilizer can be attributed to the fertilizer source exclusively. The variation of sulphate concentration with time for the two fertilizers is presented (Fig. 5). It can be observed from the data that at the start of the experiment, a maximum concentration of 12201.48 $\mu \mathrm{gg}^{-1} \mathrm{SO}_{4}{ }^{2-}$ is observed in the leachate from pure $\left(\mathrm{NH}_{4}\right)_{2} \mathrm{SO}_{4}$ followed by $8537.81 \mu \mathrm{g} \mathrm{g}^{-1} \mathrm{SO}_{4}{ }^{2-}$ from sulphur-loaded surface modified nano-zeolite. The data reveal that all of the available $\mathrm{SO}_{4}{ }^{2-}$ in pure $\left(\mathrm{NH}_{4}\right)_{2} \mathrm{SO}_{4}$ is exhausted after $384 \mathrm{~h}$ while the release of $\mathrm{SO}_{4}{ }^{2-}$ from sulphate-loaded surface modified nano-zeolite is continued even after $912 \mathrm{~h}$, with concentrations ranging from 47.56 to $8.27 \mu \mathrm{g} \mathrm{g}^{-1}$. The results clearly demonstrate the slow release of sulphate from Sulphate -loaded surface modified nano-zeolite. This slow release of sulphate may be attributed to the surface modified nano-zeolite based sulphur fertilizer are slowly soluble thereby steady release $\mathrm{SO}_{4}{ }^{2-}$ was achieved because of huge number of pores, cages and channels present in the zeolite structure which hold the $\mathrm{SO}_{4}{ }^{2-}$. Bansiwal et al. (2006) studied the release of phosphate from phosphorous (P) loaded surface modified zeolite and pure potassium dihydrogen phosphate $\left(\mathrm{KH}_{2} \mathrm{PO}_{4}\right)$ in which results showed that $\mathrm{P}$ release from fertilizer-loaded SMZ was available even after $1080 \mathrm{~h}$ of continuous percolation, whereas $\mathrm{P}$ from $\mathrm{KH}_{2} \mathrm{PO}_{4}$ was exhausted within $264 \mathrm{~h}$.

\section{Conclusion}

It was concluded that the zeta potential of surface modified nano-zeolite before sulphate loading was positive charge, after the sulphate attachment in surface modified nano-zeolite that charge shifted into negative. Imaged the sulphate loaded surface modified nano-zeolite in the SEM which showed that irregular flake like structure besides Raman spectroscopy, FTIR and XRD study confirmed the sulphate attachment in the surface modified nano-zeolite. Finally, the percolation reactor study showed that $\mathrm{SO}_{4}{ }^{2-}$ release from fertilizer-loaded SMNZ was available even after $912 \mathrm{~h}$ of continuous percolation, whereas $\mathrm{SO}_{4}{ }^{2-}$ from $\left(\mathrm{NH}_{4}\right)_{2}$ $\mathrm{SO}_{4}$ was exhausted within $384 \mathrm{~h}$. These properties suggest that SMNZ has a great potential as the fertilizer carrier for slow release of $\mathrm{SO}_{4}{ }^{2-}$.

\section{ACKNOWLEDGEMENT}

The authors are grateful to Department of Science and Technology (DST), Government of India, New Delhi, for sponsoring a DST Nano Mission Project "Fabrication of Nano-Agricultural Inputs for Groundnut Productivity and Environmental Safety" (NS 89/2010).

\section{REFERENCES}

Alizera, N. E. and Gholamhosein, R. (2012). Modification of nanoclinoptilolite zeolite with Hexadecyltrimethyl ammonium surfactant as an active ingredient of chromate-Selective Membrane Electrode. Journal of chemistry, 20(13): 1-13.

Bansiwal, A.K., Rayalu, S.S., Labhasetwar, N.K., Juwarkar, A.A. and Devotta, S. (2006). Surfactant modified zeolite as a slow release fertilizer for phosphorus. Journal of Agricultural and Food Chemistry, 54: $4773-4779$.

Biederbeck, V. O. (1978). Soil organic sulphur and fertility. In: M. Schnitzer, and S. U. Khan (Ed.), Soil Organic Matter, Developments in Soil Science Vol. 8, Amsterdam (pp, 273-310): Elsevier Scientific Publishing Company.

Boswell, C. C. and Gregg, P. E. H. (1998). Sulfur fertilizer in grazed management systems. In: D. G. Maynard (Ed.), Sulfur in the environment, New York (pp 95135): Marcel Dekker.

Bowman, R. S. (2003). Applications of surfactant-modified zeolites to environmental applications. Microporous Mesoporous Materials, 61: 43-56.

Bowman, R. S., Haggerty, G. M. Huddleston, R. G. Neel, D. and Flynn, M. M. (1995). Sorption of nonpolar organic compounds, inorganic cations and inorganic oxyanions by surfactant-modified zeolites. In: D. A. Sabatini, R. C. Knox and J. H. Harwell (Eds.), Surfactant-enhanced subsurface remediation, vol. 594 of ACS Symposium series, (pp, 54-64), American chemical society, Washington, DC, USA.

Choudhury, S. R., Nair, K. K., Kumar, R., Gogoi, R. and Srivastava, C. (2010). Nanosulfur: A potent fungicide against food pathogen, Aspergillus niger. In: American Institute of Physics Conference Proceedings, 1276: 154-157. Springer Berlin Heidelberg, USA. 
Coleman, R. (1966). The importance of sulphur as a plant nutrient in world crop production. Soil Science, 101: 230-239.

Dutta, P.K., Shieh, D.C. and Puri, M . (1988). Correlation of framework Raman bands of zeolites with structure. Zeolites, 8: 306-309.

Glanigen, E. M. (1976). Zeolite Chemistry and Catalysis. ACS Monograph Ser., 171: 93.

Gupta, R. P. and Dhakshinamurthi, C. (1980). Procedures for physical analysis of soils and collection of agrometerological data division of agricultural physics, IARI, New Delhi.

Haggerty, M. G. and Bowman, S. R. (1994). Sorption of chromate and other inorganic anions by organo-zeolite. Environmental Science and Technology, 28(3):452-458.

Hanway, J. J. and Heidal, H. (1952). Soil analysis methods as used in Iowa state college soil testing laboratory. Lowa State College Agricultural Bulletin, 57: 1-13.

Himmel, D., Maurint, L. C., Grost, O. and Mansot, J. L. (2009). Raman microspectrometry sulfur Detection and characterization in the marine ectosymbiotic nematode (Eubostrichus dianae). Biololg of the Cell, 101: 43-54.

Inglezakis, L.V., Loizidou, M. D. and Grigoropoulou, H. (2001). Pretreatment of clinoptilolite in ion exchange packed beds. In: 7th International Conference on Environmental Science and Technology, September, Greece.

Inglezakis, L.V. and Grigoropoulou, H. (2004). Effects of operating conditions on the removal of heavy metals by zeolite in fixed bed reactors. Journal of Hazardous Materials, B112: 37-43.

Jackson, M. (1973). Soil chemical Analysis, Pentice Hall of India Pvt. Ltd., New Delhi, India.

Kesraoui-Ouki, S., Cheeseman, R. C. and Perry, R. (1994). Natural zeolite utilization in pollution controls: A review of applications to metals effluents. Journal of Chemical Technology and Biotechnology, 59(2):121126.

Kumar, R., Nair, K. K., Alam1, I., Gogoi, R., Singh, P. K., Srivastava, C., Yadav, S., Gopal, M., Chaudhary, S. R., Pradhan, S. and Goswami, A. (2011). A simple method for estimation of sulphur in nanoformulations by UV spectrophotometry. Current Science, 100(10): 1542-1546.

Li, Z., Anghel, I. and Bowman, R. S. (1998). Sorption of oxyanions by surfactant modified zeolite. Journal of Dispersion Science and Technology, 19: 843-857.

Li, Z. and Zhang, Y. (2010). Use of surfactant-modified zeolite to carry and slowly release sulfate. Desalination and Water Treatment, 21:73-78.

$\mathrm{Li}, Z$. (2003). Use of surfactant-modified zeolite as fertilizer carriers to control nitrate release. Microporous and Mesoporous Materials, 61: 181-188.

Lindsay, W. L. and Norvell, W. A. (1978). Development of a DTPA soil test for zinc, iron, manganese and copper. Soil Science Society of America Journal, 42 :421-428.

Nikolakis, V. (2005). Understanding interactions in zeolite colloidal suspensions: A review. Current Opinion in Colloid and Interface Science, 10: 203-210.
Olsen, S. R., Cole, C. V., Watanabe, F. S. and Dean, L. (1954). Estimation of available phosphorus in soils by extraction with sodium bicarbonate U.S.D.A. Circ. 939. U.S. Govt. Printing Office, Washington, DC.

Perrin, T. S., Drost, D. T., Boettinger, J. L. and Norton, J. M. (1998). Ammonium-loaded clinoptilolite: A slow-release nitrogen fertilizer for sweet corn. Journal of Plant Nutrition, 21:515-530.

Sakal, R. and Singh, A. P. (1997). Sulphur in balanced fertilisation in Eastern India. In: Proceeding of The Suphur Institute (TSI) /Fertiliser Association of India (FAI) / International Fertiliser Industry Association (IFA) Symposium on Sulphur in Balanced Fertilisation, held on 13-14 February, New Delhi, pp. SI-2 / 1-6.

Santhosh kumar, M. (2012). Synthesis and characterisation of nano-gypsum for effective remediation of sodic soil in rice (Oryza sativa L.). M.Sc. (Ag.) Thesis, Tamil Nadu Agricultural University, Coimbatore.

Scarano, D., Zecchina, A., Bordiga, S., Geobaldo, F., Spoto, G., Petrini, G. Leofanti, G., Padovan, M. and Tozzola, G. (1993). Fourier-transform infrared and Raman spectra of pure and $\mathrm{Al}-$, B-, Ti- and $\mathrm{Fe}-$ substituted silicalites: stretching-mode region. Journal of Chemical Society, 89: 4123-4130.

Schollenberger, C. J. and Dreibelbis, F. R. (1930). Analytical methods in base exchange investigation in soils. Soil Science, 30: 161- 173.

Sharmila Rahale, C. (2010). Nutrient release pattern of nano -fertilizer formulations. Ph. D. Thesis, Tamil Nadu Agricultural University, Coimbatore.

Smirnov, K. S. and Bougeard, D. (1993). Raman and infrared spectra of siliceous faujasite-A molecular dynamics study. Journal of Raman Spectroscopy, 24: 255 -257 .

Srinivasulu, B., Bhadra Dev, P. and Murthy, P. H. C. (2012). X-ray diffraction of samaguna balijarita kajjali (black sulphide of mercury). International Journal of Research in Ayurveda and Pharmacy, 3(4): 524-527.

Subbiah, B. V. and Asija, G. L. (1956). A rapid procedure for estimation of available nitrogen in soils. Current Science, 25: $259-260$.

Subramanian, K. S. and Sharmila Rahale, C. (2012). Ball Milled Nanosized zeolite loaded with zinc sulfate: A putative slow release $\mathrm{Zn}$ fertilizer, International Journal of Innovative Horticulture, 1: 33-40.

Tabatabai, M. A. (1982). Sulfur. In: A. L. Page, R. H. Miller and D. R. Keeney (Eds.), Methods of soil analysis, Part 2: Chemical and microbiological properties, (pp. 501-538) American Society of Agronomy, Madison, WI.

Walkley, A. and Black, C. A. (1934). An Examination of the degitijareff method for determining soil organic matter and a proposed modification of the chronic acid titration method. Soil Science, $40: 233-243$.

Williams, C. H. and Steinbergs, A. (1959). Soil sulphur fractions as chemical indices of available sulphur in some Australian Soils. Australian Journal of Agricultural Research, 10: 340 -352. 